\title{
CIRCULATION AT RUSSIAN-BALTIC STATES BOUNDARY: A CUT AND A SEAM
}

\author{
ARNAUd SERRY ${ }^{1}$ \\ CEDETE - University of Orleans (France)
}

\begin{abstract}
Disintegration of the USSR and join of Baltic States to European Union made this one a border territory between Russia and EU. After the collapse of Former Soviet Union, the new boundary remained almost easy to cross. In the beginning of the 21th century, it became no more fuzzy but rather fixed. Since European enlargement that had taken place in 2004, the crossing has become more regulated. People need visas that meant administrative papers and cost. The evolution of cargo flows has been more contrasted. Economic policies, political stakes and traditional links, are elements to understand East Baltic area. Kaliningrad Oblast, the Russian exclave lying by the Baltic Sea, strengthens the interest of the purpose.

KEY WORDS: circulation, border, Baltic States, discontinuity.
\end{abstract}

JEL CODES: O180, R400

\section{Introduction}

After the collapse of the USSR and the enlargement of the European Union to the Baltic, their eastern border became the border between Russia and EU. This paper focuses on flows of goods and persons through boundaries between Russia, and Baltic states (Estonia, Latvia and Lithuania). The purpose is to analyze the role of this boundary after the enlargement of the EU.

Thus, the independence of the Baltic early in 1990 and EU enlargement of 1 May 2004, displaced the European Union border to the east, introducing a discontinuity in the area of the eastern Baltic. Meanwhile, this border improved, reactivated, and in particular by increased flows' controls. However, this border space is an area of significant exchanges with Russia and Belarus, including trade, tourism and travel. Scale games are omnipresent in the apprehension of this new discontinuity and its impact on mobility and cross-border traffics.

\section{The context}

The geographic characteristics of the region give to the Baltic-Russian border a central role in Russian international trade relations: spatial link between the northern, western, central and eastern Europe, trading hub are to define the Baltic sea.

\footnotetext{
Arnaud Serry - University of Orléans, Department of Management, assoc. prof. dr., scientific interest: Logistics and Transport, Geography.

E-mail: arnaud.serry@univ-orleans.fr

Tel.: + 33 (0)6 23819436
} 


\subsection{Geographical}

The Russian-Baltic boundary appears as a specific space, at the intersection of two regions on the sidelines.

Is it the margins of EU and the margin of Russian Federation? So is it only a periphery, or a new center? The peripherality of the region is tempered by the strong mesh that connects the main poles of the network. The Russian-Baltic boundary is a dynamic space, and also a margin, for several reasons that this area is conducive to innovation:

- As in the periphery, it is less controlled than the central place;

- New European frontier, it is a locus where the gradients are the strongest on the shorter distance;

- Finally, many networks, physical and institutional, are crossing this space.

This border is a discontinuity between two constructed territories. It causes differences and thus induces various spatial effects. It is also a limit in highly charged symbols and representations. But it doesn't juxtapose any difference in mesh or network, because they are largely inherited from the Soviet period. At late twentieth century, when the political discontinuities have moved, transportation networks have persisted. Transport contributes, therefore, to question boundaries.

\subsection{Historical}

At the end of the Soviet period, Baltic States were mainly linked to USSR and COMECON Main international gateways were the ports. There were no international airlinks, just a few trains towards Eastern and Central Europe. In the early 90's there was a drop of the links with Former Soviet Union due to several factors: economic collapse, social crisis, nationalism.

In subsequent years, the situation has normalized, but 2004 enlargement of EU changes the nature of the border with FSU (Former Soviet Union). It displaced the European Union border to the East, introducing a discontinuity in this area of the eastern Baltic.

Trade flows implications of the Baltic-Russian border are much less studied than geopolitics: for instance, Russia often uses energy products' trade for political purposes.

\subsection{Methods}

Paper deals with theoretical and empirical research. The approach is mainly through port and railway traffics for goods, and through air networks for passenger flows. This study is therefore based on rail and air transport statistics. It also relies on the analysis of transport networks and, more particularly, on regular international lines: trains, buses and air links.

Furthermore, knowledge of the field strengthens the results and completes the reading of papers on the same theme. It makes possible the understanding of cross-border circulations in the region and helps to characterize them at different scales.

Moreover, the mapping of traffic of people and commodities establish a new perception of the impact of the new EU border in the region. It reinforces the understanding of situation and spacializes it more clearly.

\section{Cargo flows between Baltic States and Russia}

Baltic States are mainly transit territories for goods coming from or going to post-soviet states. So, the transport system is based on the complementarities of ports and railways. 


\subsection{The port system}

After the collapse of the USSR, half of the former Soviet port capacity of the Baltic sea was located outside Russia.

In the mid-1990s, Russia had to find a safe and cheap way for its products to the Atlantic. Past the time of extreme nationalism, the Baltic economic actors have realized that their domestic market could not enough and they had to use the networks and relationships forged with neighboring Russia (Serry, 2011). So, the new border between former Soviet Republics has seen the revival of traditional commercial traffics.

Today, the Baltic port range still keeps particularities of the Soviet system:

- The purpose of the port system remains mostly similar: Exports of raw materials from Russia and the CIS countries and import of manufactured goods;

- Transit flows remain the major components of port traffics.

Four features define the evolution of maritime traffic in the Baltic Range: increasing traffic of crude oil, based on Russian exports, growth of container movements, increase of intrabaltic roll on - roll of flows and geographical concentration of traffic in some ports. Today the main ports of the range are Saint-Petersburg and Primorsk oil terminal.

There is a Baltic ports range with its own characteristics and a specific organization, in which the ports have linked commons with the combination of competition, complementarities and cooperation ${ }^{2}$.

\subsection{A Soviet inheritance: the large share of railway transportation}

The following table clearly shows the regional specificity in terms of freight transport (See Table 1): it is dominated by rail, especially for international circulation. Even if rail share in freight transport is decreasing, it is still higher than in the other EU countries. Road transport is yet minor and volatile. As statistics about road transport are not available, only rail transport is here analyzed.

Table 1. Part of rail in fret transportation (\%)

\begin{tabular}{|l|c|c|c|c|}
\hline & $\mathbf{1 9 9 8}$ & $\mathbf{2 0 0 0}$ & $\mathbf{2 0 0 5}$ & $\mathbf{2 0 0 9}$ \\
\hline EU & & 19.7 & 17.7 & 16.5 \\
\hline Estonia & 67.3 & 62.7 & 64.6 & 52.7 \\
\hline Latvia & 76.0 & 73.5 & 70.2 & 69.8 \\
\hline Lithuania & 59.5 & 53.4 & 43.9 & 40.1 \\
\hline
\end{tabular}

Source: Eurostat, 2010.

Main international rail freight flows in the Baltic States concern Russia, as a result of port transit activities. For instance crude oil exported by Tallinn-Muuga is carried by rail from Russia. We can notice a spatial differentiation of intensity and distribution of international rail freight:

- In Lithuania, flows exist with most post-Soviet states (See Figure 1);

- In Latvia, the distribution of flows is much more concentrated, with the absence of the Caucasus countries;

- Estonia seems to be in an intermediate position.

There is also a phenomenon of neighborhood, for example between Lithuania and Belarus (Klaipeda exports Belarus fertilizers to EU and USA).

Apart traditional goods (metals, minerals, oil, etc.), a new kind of traffic dramatically increases: container flows.

2 Unfortunately there is little information on Russian operators and investors in the Baltic States' ports. Russian actors are present, but they are discreet to avoid offending national sensitivities. 


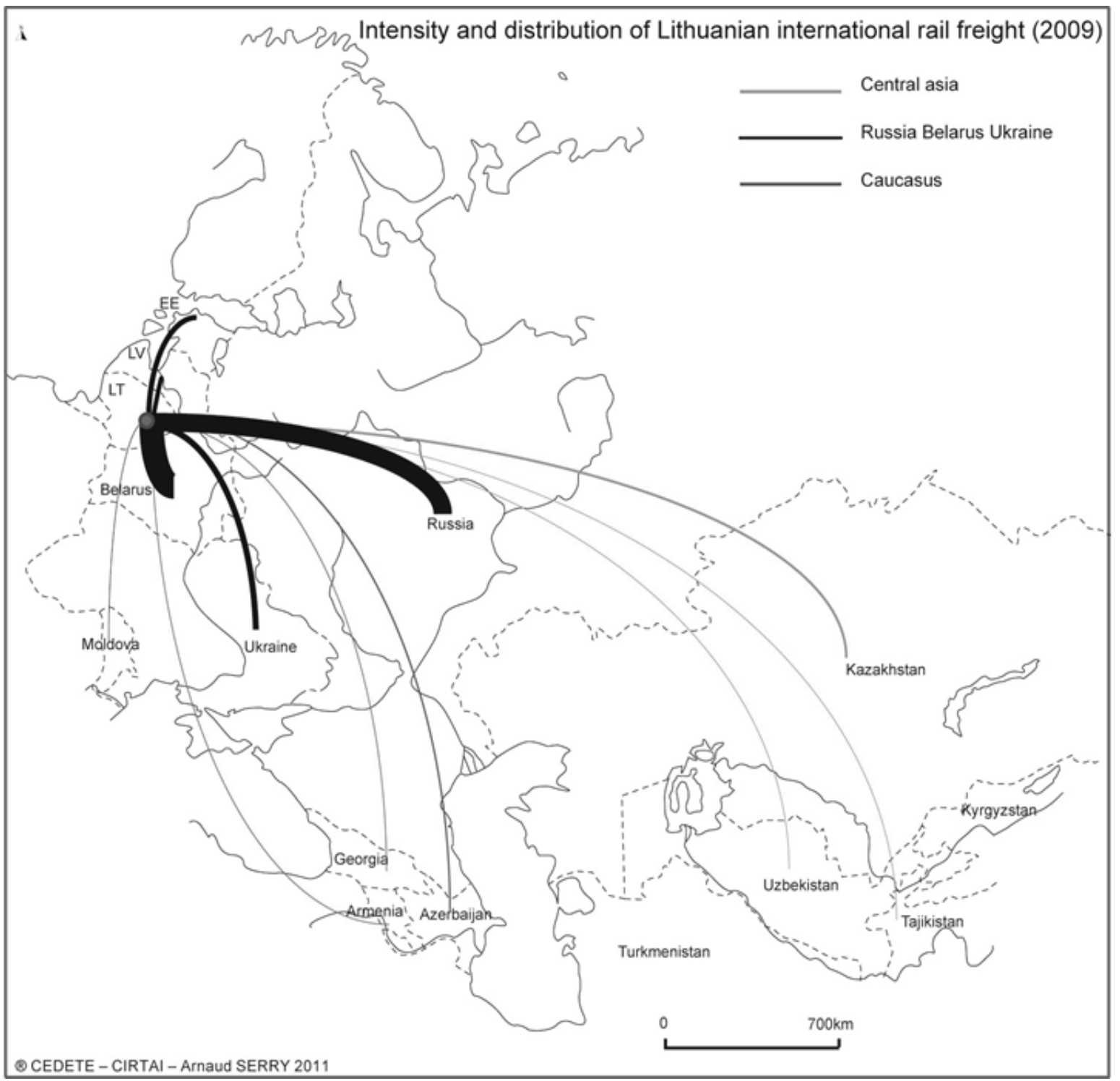

Figure 1. Lithuanian international rail freight

\subsection{Block-trains, the beginning of cooperation}

Ports, railway companies and new operators (shipping and stevedoring international companies) are setting up block-trains ${ }^{3}$ between the Baltic States and FSU and China. Block-trains enable "door-to-door" delivery, safety and easy border crossing as well as customs procedures (CIS/EU border in $30 \mathrm{~min}$ ).

The most successful pattern is the shuttle train "Viking", launched in 2003, between Klaipeda (Lithuania), Odessa and Illichivsk (See Figure 2), which carries about 40,000 TEUs per year. Railways and shipping companies, ports of Lithuania and Ukraine, cooperate to simplify customs procedures, so trains can travel in 52 hours the 1,734 kilometers that separate the two ports. Today, Georgia intends to join the Viking intermodal project. In addition, negotiations are underway with Moldova, Turkey, Syria, Azerbaijan, Finland, Sweden and Norway.

3 A block train, is a train in which all the wagons making it up are shipped from the same origin to the same destination, without being split up or stored en route. 
The "Baltica transit" is a twice weekly train-block service between Riga and Almaty (Kazakhstan). Transit time is $8-10$ days. In Latvia, the train is operated by LDZ Cargo in cooperation with FESCO (Far Eastern Shipping Co) for the Russian part.

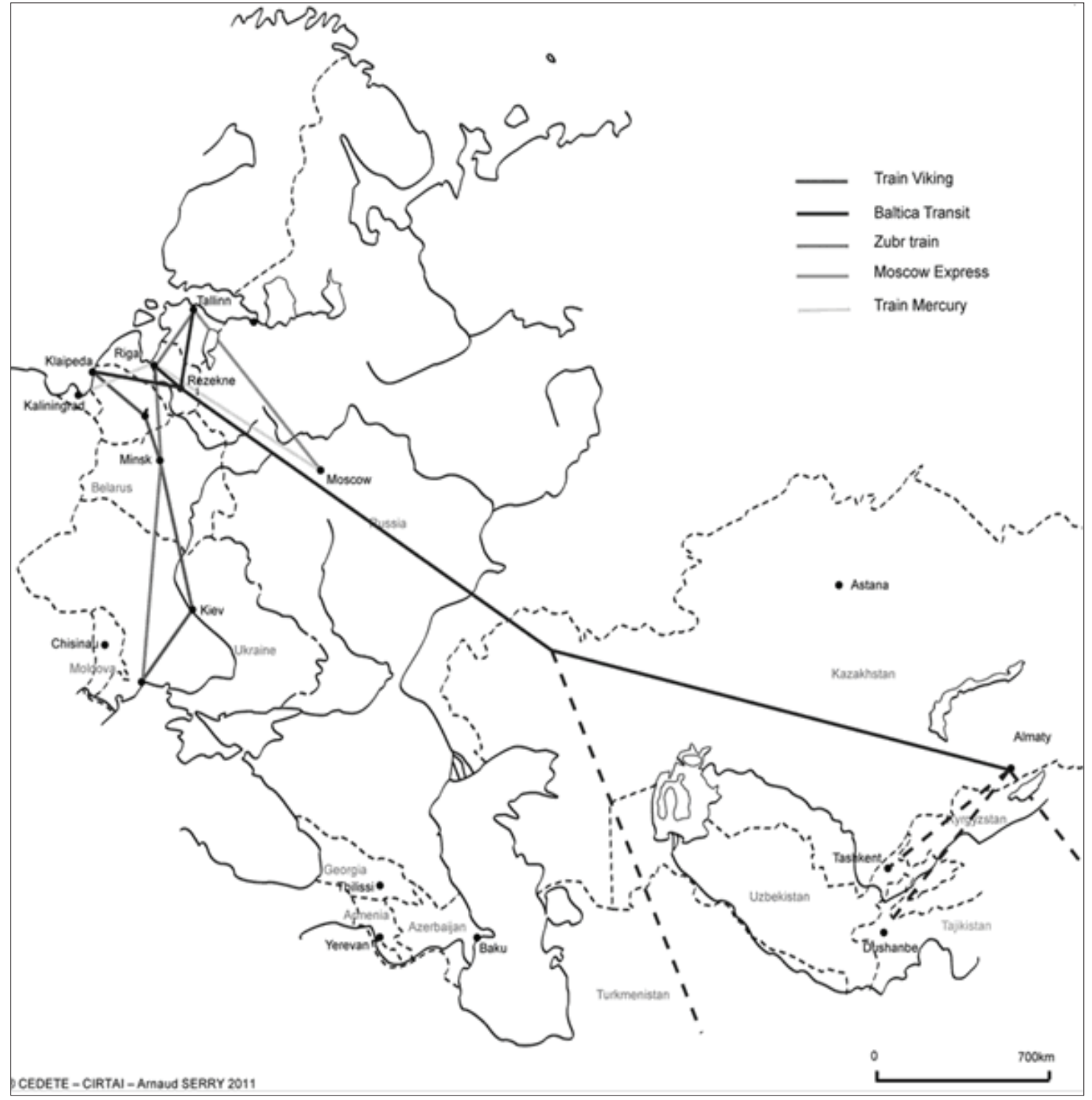

Figure 2. Block-trains between Baltic States and CIS countries

Nowadays, many projects appear. In 2012, Lithuanian and Russian railways are planning a container train Mercury between the ports of Kaliningrad and Klaipeda and logistics centers in Moscow. AS Baltic Rail wants to develop scheduled container trains from Šeštokai to St. Petersburg, Moscow and Central Asia. The choice of Šeštokai railway station is not trivial because it is the oriental terminus of European gauge railway lines. The idea is to make this technical constraint an asset for the development of network interoperability, particularly with the forthcoming opening of the Rail Baltica.

\subsection{Cross border entrepreneurship}

The first economic opportunity lies in the existence of old economic partners. Trade relations have developed on a foundation derived from past acquaintances. The main advantages of trade between Baltic States 
and Russian and Belarusian border regions are to find raw materials at a lower price or find a larger market for goods, services, or tourism activities.

Border trade is boosted by a multitude of regional companies. Business collaborations are more present in the border regions of the Baltic States than on their coastlines. Small structures benefit from the vagueness of the law to trade without taxes. These commercial flows regularly take the appearance of cross-border business cooperation, the most developed forms are:

- Export of certain Baltic productions (dairy products, paints, packaging...);

- Russian Imports of goods in the Baltic States (rubber, wood, fish, fuel...);

- Recreation and accommodation for the Russian or Belarusian people;

- Transport services (cars, people).

The rapid economic development of the Baltic States has caused some differences in price levels, which favors the interest of entrepreneurs in cross-border trade, although the price difference has decreased. Moreover, the Baltic accession to the EU amended the legislation particularly with regard to imports from third countries. In contrast, the large Russian market remains attractive for Baltic businessmen.

\section{People circulation particularities}

\subsection{Main international passenger flows}

In the region, means distribution of international transport of passengers is similar to the traditional division: domination of the air but rail and road has still a significant share.

In the Soviet past, all the regular commercial flights in the Baltic republics airports were flown as domestic, inside USSR. After the independences the network changed dramatically. Today less than $20 \%$ of the destinations of Baltic airports are located in FSU. A long time second after Vilnius, Riga airport is now the first one in the Baltic states for passengers carried and movements (4.6 million and 68145 in 2010 respectively). It is also the first by the number of FSU destinations. This is a consequence of the firm strategy of Air Baltic, the main air company in the region. It created a hub in Riga in 2004, working as a gate-way between EU and FSU (See Figure 3).

During the 90's flows and flights decreased even to $100 \%$. Many destinations in FSU were closed. In the beginning of the $21^{\text {st }}$ century, more flights are operated, mainly with the capitals (Moscow and Kiev). But flights to other towns are not yet re-operated. Priority for Baltic States air network is development of links with the EU. After exclusive links, to USSR, then to EU, Riga airport and Air Baltic intend to win a central position in the middle of the two regions.

The Baltic Soviet republics were in direct railway connections with many towns of the USSR, even in its Asian territory. Those links disappeared in the beginning of the 90's. Today, apart Kaliningrad, the only remaining trains travel to the capitals of the neighbor countries.

Road transport is difficult to analyze due to lack of reliable information. I tried to use busses schedules, network maps and global statistics. Road transport seems to have an important place in cross-border flows, probably in relation with little cross-border business (See Figure 4). After the entrance of the Baltic States in the Schengen area, visas were introduced. Therefore regional international passenger flows decreased. 


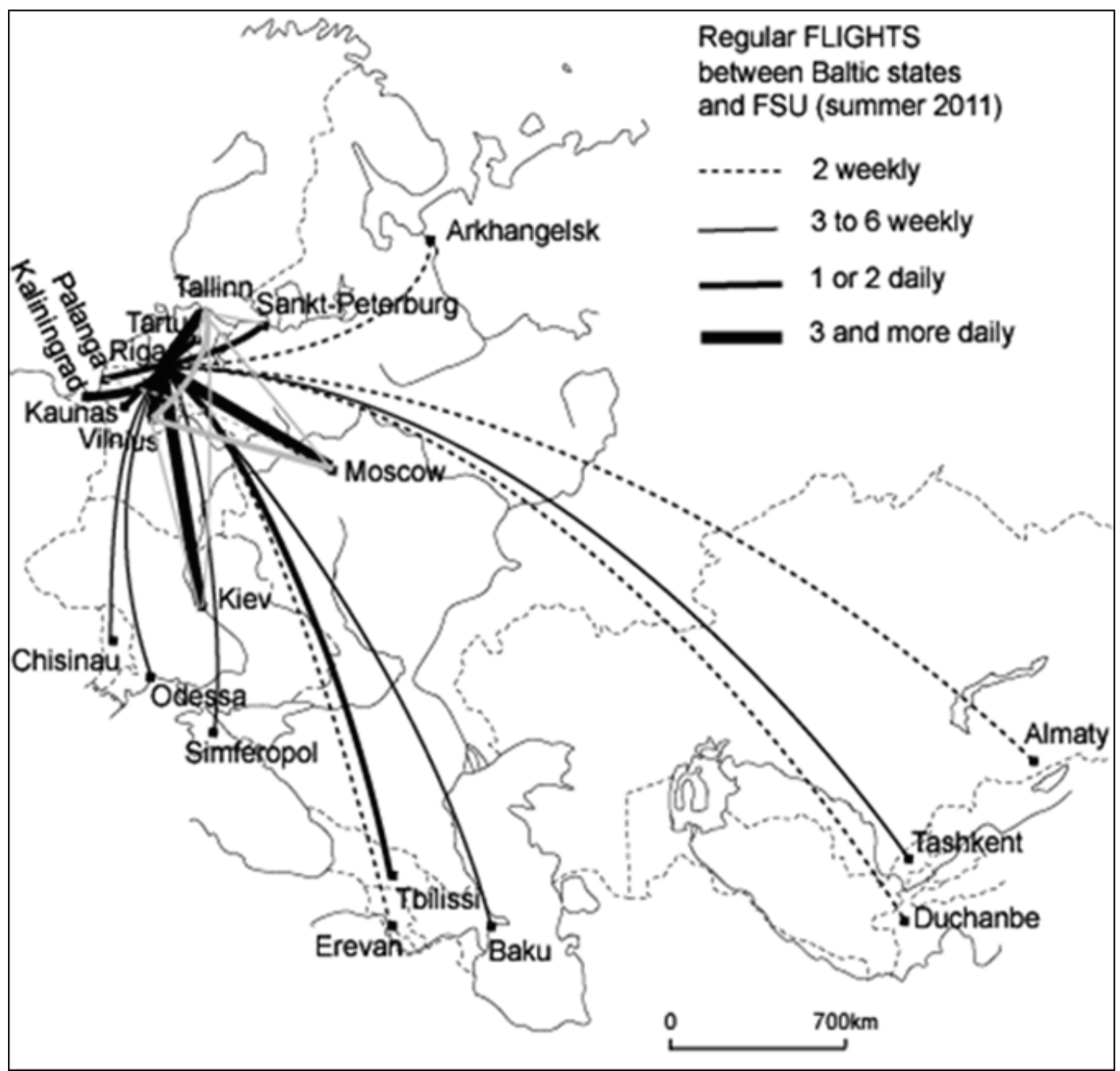

Figure 3. Regular flights between Baltic States and FSU Source: Serry, Thorez, 2011.

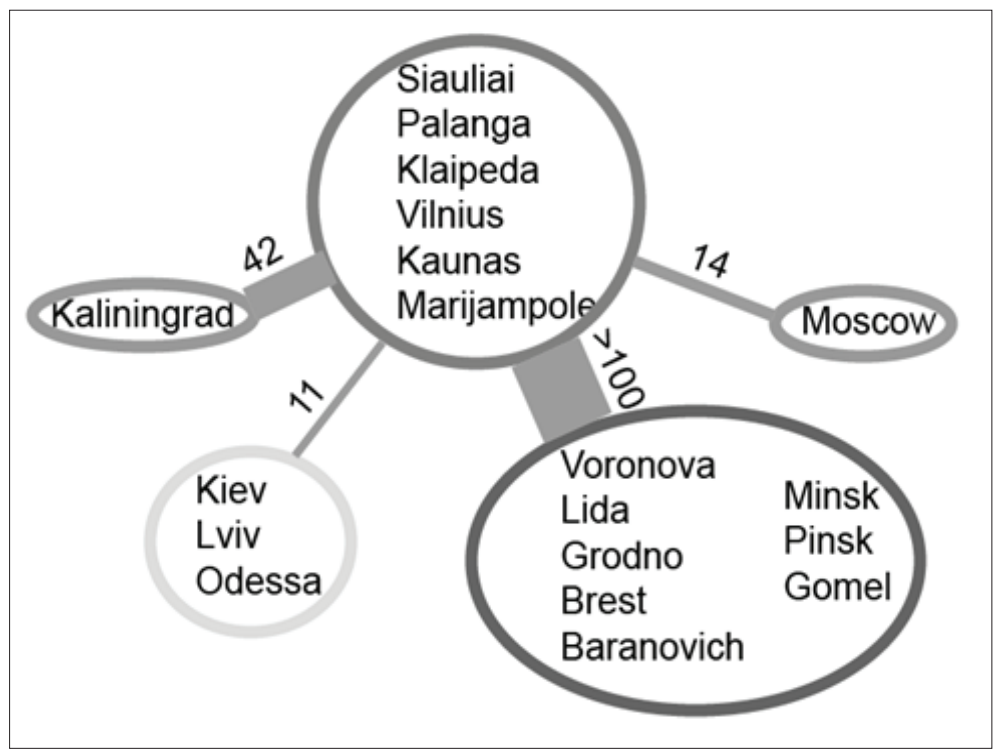

Figure 4. Lithuania, international busses Source: Serry, Thorez, 2011. 
But it is impossible, without personal enquiry at the border cross-points to evaluate individual car international flows. Obviously, there is a lot of "Tchelnoki"4 from both side of the border.

\subsection{Shuttle trade}

The opening of borders in the early 1990's has instantly resulted in the development of a specific type of cross-border mobility. This is the small business or commercial tourism, also called suitcase trade.

Border trade has mainly developed because of economic or fiscal differentials. Many people embrace the border to make money. To do this, some did not hesitate to travel hundreds of kilometers under very uncomfortable conditions. Hundreds of thousands of people have specialized in their suitcase using the slight differences in prices (see Table 2). Some goods are cheaper in Russia. The favourite products are cigarettes and vodka. All border regions have benefited from trade in goods.

Table 2. Prices comparison

\begin{tabular}{|l|c|c|c|c|c|}
\hline August 2008 (€) & Finland & Estonia & Latvia & Lithuania & Russia \\
\hline Box of cigarettes & 3.85 & 1.90 & 2.00 & 1.73 & 0.90 \\
Litre of petrol & 1.50 & 1.08 & 1.17 & 1.10 & 0.77 \\
\hline
\end{tabular}

Source: Orcier, 2009

In fact, the phenomenon has different spatial effects like open sky markets or specific flows in some areas. Markets, mostly informal, are created along the borders, like in Gariūnai near Vilnius. Currently, this small business takes place mainly from Russia to the Baltic States, as a price difference persists. But the suitcase trade had to adapt to a new configuration from December 2007 and the entry of the Baltic States into the Schengen area. In many ways, the introduction of visas has been felt as a step backwards. So, the EU has allowed short-stay visas. Even so, this permit is limited to the border area. Last but not least, for those reasons, nowadays shuttle trade decreases.

\section{Two particular situations}

\subsection{The case of Narva-Ivangorod}

The question of discontinuity is reinforced in some cases, particularly in a border town like Narva (67,000 inh.), the easternmost and second Estonian city. The city is $90 \%$ Russian-speaking, situation inherited from the Soviet period. On the right bank of the river, lies Ivangorod, a small Russian town of 10,000 inhabitants (Orcier, 2009). Russian citizens of Narva, which have a permanent residence permit, can travel to Russia with their simple passport. Estonian citizens need a visa to cross the border.

The price differences is generating constant back-and-forth border of the inhabitants of Narva (two million crossings each year). There is no city bus connecting Ivangorod to Narva. Thus, residents wishing to visit the other side must do it by foot. A passage and a checkpoint for pedestrians have been built. The border crossing in Narva is thus characterized by a continuous queue of pedestrians.

Even if trade is now more difficult, it is estimated that only $5 \%$ of people enter the Russia as tourists or for business. All others go to Ivangorod, where gas stations have sprung up, to buy petrol and then return to Narva. They are called "benzovoz". A system of queuing tickets was established, with two ways to cross the border. The "benzovoz" can "queue up" at home. For this, they withdrew a ticket with their car registration

\footnotetext{
4 The term refers to inhabitants of border regions, who live traffic of vodka, cigarettes and fuel.
} 
number and their place in the queue. They follow the movement of the tail from their computer and, when their turn comes, they drive to the checkpoint, and then to Ivangorod.

Narva-Ivangorod seems emblematic of an exceptional border situation because. It became a gateway to the European Union but a deadbolt for local population mobility.

\subsection{Kaliningrad oblast}

After the independence of Lithuania, Kaliningrad became separated from the Russian Federation. The enclave raises many questions related to the problems of discontinuity:

- Problems of territory discontinuity. For Kaliningrad oblast, crossing the borders does not necessary means going abroad, but going to the heartland;

- Mobility freedom between the enclave and the Russian territory. Since 2007, all the habitants of Kaliningrad, need a Schengen visa to enter Poland and Lithuania;

- Differences in prices and economic conditions on both sides of the border which can generate a vital cross-border trade. Although the standard of living in the enclave is greater than the Russian average, it remains well below Lithuanian and Polish ones.

Suitcase trade, legal or illegal, was very well developed before EU enlargement. After EU enlargement, 2004 data's show the negative impact on border crossings. The number of persons crossing the border decreased by 9.1 million in 2002 to 7,000,000 in 2004 (see table 3). In fact, this decline is mainly due to the gradual decrease in the activities of border trade. It is mainly due to two following reasons:

- first, stricter custom controls at borders and probably a decline in corruption due to the presence of the customs of other EU states;

- secondly, the introduction of visa regime with Lithuania.

Table 3. Border crossing evolution

\begin{tabular}{|l|c|c|c|c|c|c|}
\hline \multicolumn{1}{|c|}{ Border crossing (Millions) } & $\mathbf{1 9 9 9}$ & $\mathbf{2 0 0 0}$ & $\mathbf{2 0 0 1}$ & $\mathbf{2 0 0 2}$ & $\mathbf{2 0 0 3}$ & $\mathbf{2 0 0 4}$ \\
\hline People & 8.6 & 8.9 & 9.0 & 9.1 & 7.9 & 7.0 \\
\hline Cars & 2.9 & 3.1 & 3.1 & 3.1 & 3.3 & 2.9 \\
\hline
\end{tabular}

Source: Vinokourov, 2007.

When speaking about circulation, the traditional means of transport between Kaliningrad oblast and the

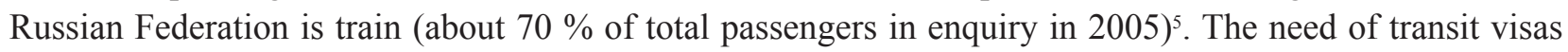
impacted passenger practice towards air companies. In 2011, there are still 2 daily trains between Kaliningrad and Moscow, but not less than 10 daily flights. In addition, railway remains dominant for freight with a share of about $80 \%$. But fees for transit are higher for Russian imports and exports, than using Baltic States or "continental" Russian ports. Moreover, Russian shipping companies operate ro-ro and container ships between Ust-Luga and Kaliningrad in order to insure the supply of the oblast.

As a final point about Kaliningrad, the border became a factor of territorial discontinuity for Russian Federation. It is a drawback to Russian flows.

International Organization for Migration, Vilnius office, Migration and transit as seen by Kaliningrad population, Representative public opinion survey of the Kaliningrad population, 2005 
Conclusions

The dichotomy of cross border circulations is evident:

- Massive and long-distance trade flows, continental or intercontinental, are based on a specific transport system giving to the region a gateway vocation;

- Short and diffuse traffics are needed for local people or regional development.

As wrote Claude Raffestin ${ }^{6}$, the border between Russia and the Baltic States has contradictory impacts: it is a cut and a seam. In a general evolution characterized by traffic drop in the early 90's followed by recovery after 1999 and growth in the 2000's, borders are easily crossed by international and transit flows organized by international operators. Business and practices are against political borders. Ports are positioned as gateways between Russia and Europe and participate in the building of a single integrated reticular regional space.

At local scale the border became a frontier. Local mobility, especially cross-border practice, is now more difficult.

We could conclude that the border is a seam in global transport system, but a cut in local mobility. There is an evident need of cooperation between EU and Russia to facilitate mobility and circulation of population across the border.

\title{
References
}

Guichonnet, P., Raffestin, C. (1974). Géographie des frontiers. Puf.

Lobtach, A. (2005). Belarus on the EU borders: The impact of enlargement on trade and cross-border cooperation. Institute for world economies Working papers, $17 \mathrm{p}$.

Orcier, P. (2009). Les recompositions territoriales dans la région de la Baltique orientale (Finlande, Estonie, Lettonie, Lituanie), Thèse de Géographie, Ecole Normale Supérieure - Lettres et Sciences humaines, $447 \mathrm{p}$.

Serry, A. (2011). La réorganisation portuaire de la Baltique orientale - L'émergence d'une nouvelle région en Europe. Editions Universitaires Européennes, 376 p.

Serry, A., Thorez, P. (2011). The Russian-Baltic states boundary: a limit between peripheries or a link between European Union and the post-soviet states. ASN Conference "Twenty Years after 1991: The Reshaping of Space and Identity". Moscow.

Vinokourov, E. (2007). L'enclave russe de Kaliningrad: spécificité territoriale et intégration à l'économie mondiale. Thèse de doctorat, Université de Grenoble, 409 p.

\section{CIRKULIACIJA RUSIJOS IR BALTIJOS ŠALIŲ PASIENYJE: APRIBOJIMAI IR SANDÜRA}

\author{
ARNAUD SERRY
}

CEDETE - Orleano universitetas (Prancūzija)

\section{Santrauka}

Šiame straipsnyje nagrinejjamas prekių ir žmonių judejjimas tarp Rusijos ir Baltijos šalių (Lietuvos, Latvijos ir Estijos). Straipsnio tikslas - išanalizuoti šių ribų vaidmenį išsiplètus Europos Sajungai.

Sugriuvus TSRS ir Baltijos šalims įstojus į ES, siena tarp šitų valstybių tapo riba, kuri skiria ES nuo Rusijos. Periferinès ES Baltijos šalys, kaip ir Vakarų Rusija, visada buvo tranzitinès teritorijos, kurioms buvo būdinga didelè žmonių ir prekių cirkuliacija. Baltijos šalys iš esmès ir liko tranzitinès teritorijos prekèms,

6 Raffestin, C. (1986). Éléments pour une théorie de la frontière. Diogène, ${ }^{\circ} 134$. 
kurios juda iš ir i posovietines valstybes, jų transporto sistema paremta uostų ir geležinkelių suderinamumu. Ekonominè politika, politiniai sprendimai ir tradiciniai ryšiai leidžia geriau suprasti Rytų Baltijos regiona. Pagrindiniai krovinių srautai Baltijos šalyse juda iš Rusijos, tačiau ne tik - svarbios ir Kaukazo bei Centrinès Azijos valstybès, susijusios su Baltijos šalimis.

Regiono tarptautinio keleivių transporto sistema panaši i tradicinę: vyrauja oro transportas, nors išlieka svarbūs ir geležinkeliai bei kelių transportas. Atgavus nepriklausomybę, skrydžių skaičius iš Baltijos šalių nuolatos didejjo: Rygos oro uostas šiuo metu yra didžiausias keleivių vežèjas Baltijos šalyse.

Būdingas savitas pasienio mobilumas: smulkiojo verslo arba komercinis turizmas. XXI a. pradžioje jis tapo nuolatinis, išsiplètus ES sienos kirtimas labiau reguliuojamas. Žmonėms reikia vizų, kurių išdavimas susijęs su administraciniais dokumentais ir išlaidomis, taigi kirsti sieną tapo sudetingiau. Tam tikrais atvejais, tokiais kaip Kaliningrado sritis ar Narva-Ivangorod miestai, siekiama gerinti padèti. Taigi vietos lygmenyje siena tampa skiriamaja riba, kuri mažiau pastebima vertinant didesnès apimties ir nuotolių prekybos srautus.

PAGRINDINIAI ŽODŽIAI: cirkuliacija, siena, Baltijos šalys, netolydumas.

JEL KLASIFIKACIJA: O180, R400 